\title{
Review
}

\section{How it all Started: Tau and Protein Phosphatase 2A}

\section{Dedicated to Inge Grundke-Iqbal}

\author{
Chang Liu ${ }^{\mathrm{a}}$ and Jürgen Götz ${ }^{\mathrm{a}, \mathrm{b}, *}$ \\ ${ }^{a}$ Brain and Mind Research Institute, University of Sydney, Camperdown, NSW, Australia \\ ${ }^{\mathrm{b}}$ Centre for Ageing Dementia Research (CADR) at the Queensland Brain Institute (QBI), The University of \\ Queensland, Brisbane, QLD, Australia
}

Accepted 25 April 2013

\begin{abstract}
This review is dedicated to Inge Grundke-Iqbal who laid the foundations of the tau field, by isolating tau from the Alzheimer's disease (AD) brain, discovering that tau is hyperphosphorylated, and proving a critical role of protein phosphatase $2 \mathrm{~A}(\mathrm{PP} 2 \mathrm{~A})$ and its endogenous inhibitor $\mathrm{I}_{2}{ }^{\mathrm{PP} 2 \mathrm{~A}}$ in this process. This memorial starts with a few personal notes, and then covers how subcellular fractionation helped in isolating tau. We review in detail the role of PP2A and its endogenous inhibitor in tau phosphorylation. We discuss the role that methylation and phosphorylation have in regulating PP2A activity. We add what we have contributed to understanding the role of tau and PP2A in AD using PP2A transgenic and knockout models, and conclude by addressing two underexplored areas in tau research: tau's non-canonical functions and the role distinct tau isoforms have in a physiological context.
\end{abstract}

Keywords: Alzheimer's disease, frontotemporal dementia, nucleus, protein phosphatase 2A, SFPQ, tau, transcription factor

\section{INTRODUCTION}

My first visit to New York dates back more than twenty years. At the time, I was a postdoctoral fellow at the University of California, San Francisco and had come to Cold Spring Harbor on Long Island to attend a conference on mouse genetics and transgenesis. New York was close and thus a reasonable place to visit. In these days I did not know that I would once work on tau and use tau transgenic mice as my favorite workhorse. On my second visit to New York in February 2013, I came from Australia via Vancouver, where I had attended a Keystone conference on vaccination strategies. I very much looked forward to meeting Khalid and

*Correspondence to: Jürgen Götz, Centre for Ageing Dementia Research (CADR), Queensland Brain Institute (QBI), The University of Queensland, Brisbane, QLD 4072, Australia. Tel.: +61 73346 6329; Fax: +61 73346 6301; E-mail: j.goetz@uq.edu.au.
Inge Iqbal at their institute on Staten Island, an hour's drive from Manhattan. Sadly, shortly after scheduling the day on which I would visit, Inge passed away quite unexpectedly. I had gotten to know her and Khalid as a lovely, affectionate couple whom at conferences one would mostly see together. I was wondering whether my visit would still be appropriate but reflecting on it now, I am glad that I did not cancel, as I had a chance to enquire about the beginnings of the tau field.

When I arrived on the morning of February 6, 2013, and met Khalid in his office at the New York State Institute for Basic Research (Fig. 1), he looked tired. It was obvious that he missed Inge dearly, although to some degree he was comforted by the fact that her wish had been fulfilled-being able to work in the laboratory until her final days. Together, the two had established the tau field, making countless seminal discoveries since its inception. Sitting in Khalid's office, framed 


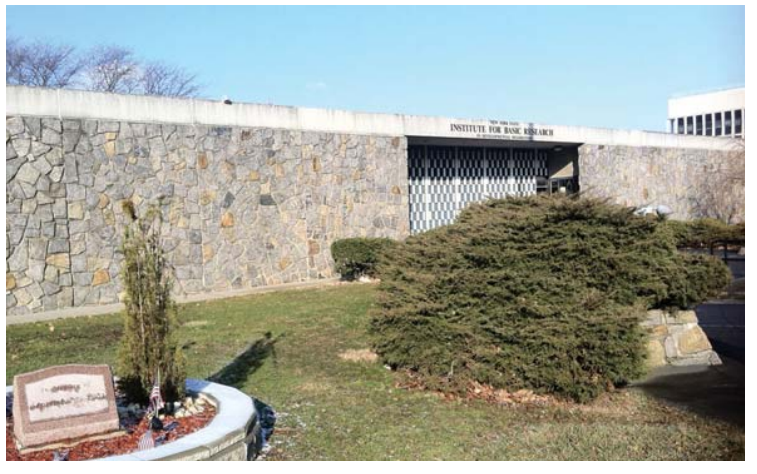

Fig. 1. Institute for Basic Research in Staten Island (NY).

by several photos taken at Christmas parties they had enjoyed together with their team, we talked about their early papers, the methodology available at the time, and what made these discoveries possible. Inge was an immunologist by training; in fact, she obtained her postdoctoral training at the Max-Planck-Institute in Freiburg (Germany), a place where I conducted my $\mathrm{PhD}$ studies many years later.

\section{SUBCELLULAR FRACTIONATION HELPS IN ISOLATING TAU}

As we skimmed through Inge's and Khalid's reprints kept in alphabetical order in several big lever arch files, we took out their first joint paper dating back to 1974 . This paper was on Huntington's disease (HD) [1]; however, their second joint paper was on tau [2]. Published in 1975 , it presented the isolation of neurofibrillary tangles (NFTs) from Alzheimer's disease (AD) tissue. Khalid told me how they had generated single cell suspensions from frozen autopsy tissue simply by utilizing endogenous proteases, and then visualized what is now known as tau, revealed as a pattern of bands on a slab gel by staining with the dye Coomassie Blue. At the time, the western blot technique was not yet available. By fractionation, Khalid and Inge determined that 'tau' was not in the nucleus. In reading the 1975 article, I have been stuck by the term 'subcellular fractionation' in assigning tau to the microtubular/cytoskeletal fraction. In the current article, we will come back to the term 'subcellular' in the context of our discovery that tau has an important physiological function not only in the axonal compartment but also in dendrites [3]. We will furthermore discuss the role of protein phosphatase 2A (PP2A), an enzyme that counteracts a set of kinases in dephosphorylating tau, and how Inge and Khalid's work inspired us to work on the role of PP2A in neurodegeneration $[4,5]$. It is an impossible task to provide an authoritative overview of the contributions and impact Inge's work had in the field; this has been best done by Khalid and Inge Iqbal themselves [6].

\section{TAU PHOSPHORYLATION, PROTEIN PHOSPHATASE 2A (PP2A), AND I ${ }_{2}^{\text {PP2A }}$}

The protein tau was first identified in brain using repeated cycles of polymerization [7]. Tau belongs to a large family of microtubule-associated proteins [8], with different models being put forward to explain how it binds to microtubules [9, 10]. A decade after its identification, it was discovered by Grundke-Iqbal and others that tau is a major antigenic component of NFTs [11-17]. Electron microscopy revealed a distinctive type of filament, termed the paired helical filament (PHF) [18]. Tau was found to be phosphorylated at multiple sites $[19,20]$, and it was realized early that abnormal phosphorylation has a crucial role in the tau pathology of AD [21, 22]. 'Hyperphosphorylation' in fact precedes the formation of NFTs [23]. Phosphorylation in general is regulated by the balanced interplay of phosphatases and kinases (Fig. 2A). Initially, calcineurin (also known as protein phosphatase 2B, PP2B) was identified as a tau phosphatase [24], and subsequently protein phosphatases 1 and 2A (PP1, PP2A) [25]. Already in those years, several kinases were shown to phosphorylate tau, including protein kinase C, calcium/calmodulin-dependent kinase, and the mitogen-activated protein kinase, ERK2 [26-28]. It soon became evident that tau undergoes a series of posttranslational modifications, with abnormal phosphorylation preceding ubiquitination [29].

When Grundke-Iqbal and colleagues measured phosphatase activities in human brain extracts, they found that of the phosphatases analyzed, the activities of PP1 and phosphotyrosyl phosphatase were significantly lower in gray matter in AD brains compared to controls, and those of PP2A in both gray and white matter, suggesting that the hyperphosphorylation of tau in AD brain could result from a protein dephosphorylation defect in vivo [30]. The team subsequently published on the role of phosphatases other than PP2A, but came back to PP2A by finding that the enzyme was able to dephosphorylate abnormally phosphorylated tau at residues Ser46, Ser199, Ser202, Ser396, and Ser404, but not Ser235 (amino acid numbering according to the largest isoform of human tau (hTau40)) [31]. Selective inhibition of PP2A by okadaic acid, using rat brain slice cultures, induced an AD-like hyperphosphorylation 
A

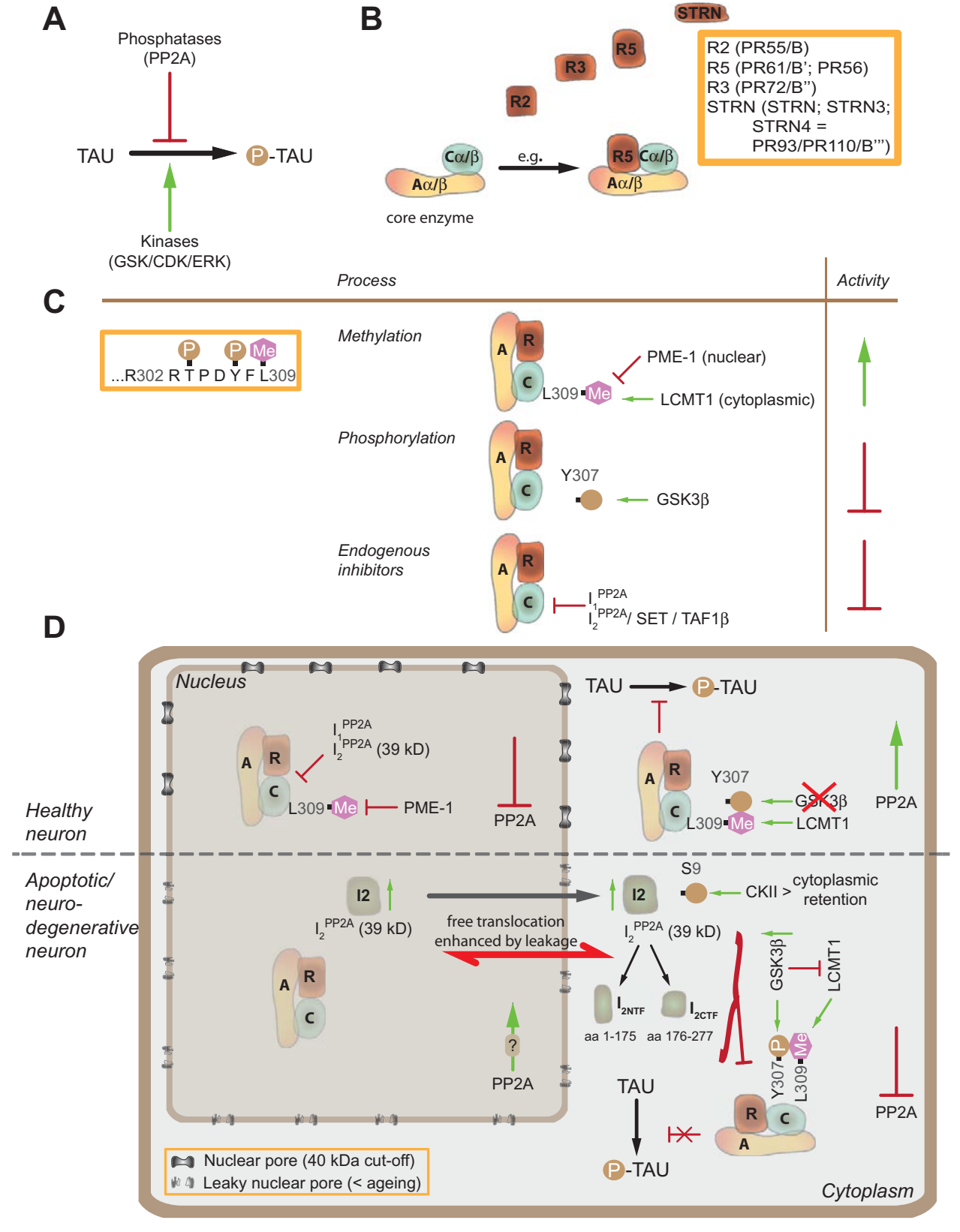

Fig. 2. The multiple layers of PP2A regulation. A) Phosphorylation of tau is a net result of the activities of kinases such as GSK (glycogen synthase kinase), CDK (cycline-dependent kinase), or ERK (extracellular signal-regulated kinase), and phosphatases such as protein phosphatase 2A (PP2A). B) PP2A is a heterotrimeric enzyme. The core enzyme is composed of a structural subunit A (that exists as two isoforms, $\alpha$ and $\beta$ ) and a catalytic subunit $C$ (that also exists as two isoforms, $\alpha$ and $\beta$ ). The core enzyme recruits regulatory subunits that compete with each other in binding. Their binding is regulated by methylation of the $\mathrm{C}$ subunit at is carboxy-terminal leucine (L309). C) The last eight amino acids of the highly conserved C subunit are shown. Leu(L) 309 is regulated by methylation employing the cytoplasmic enzyme LCMT1 (leucine carboxyl methyltransferase 1). The demethylating enzyme, PME-1 (protein phosphatase methylesterase-1), is nuclear. The $\mathrm{C}$ subunit is phosphorylated by GSK3 $\beta$ at $\operatorname{Tyr}(\mathrm{Y}) 307$. In addition, there are two endogenous inhibitors, I1 ${ }^{\mathrm{PP} 2 \mathrm{~A}}$ and $\mathrm{I}^{\mathrm{PP} 2 \mathrm{~A}}$ (also known as SET or TAF1 $\beta$ ). In general, PP2A activity is increased by methylation, and decreased by phosphorylation or via the endogenous inhibitors. D) In healthy neurons, PP2A is inactive in the nucleus and active in the cytoplasm as indicated, preventing phosphorylation of cytoplasmic tau. Under apoptotic or neurodegenerative conditions and as a consequence of ageing, nuclear pores start to leak and $\mathrm{I}^{\mathrm{PP} 2 \mathrm{~A}}$ relocalizes to the cytoplasm. Not only is $12^{\mathrm{PP} 2 \mathrm{~A}}$ cleaved into two smaller fragments that can now freely diffuse between the nucleus and cytoplasm, also, phosphorylation of $\mathrm{I}^{\mathrm{PP} 2 \mathrm{~A}}$ at $\operatorname{Ser}(\mathrm{S}) 9$ by CKII (casein kinase II) causes its retention in the cytoplasm. Together with an increased activity of GSK3 $\beta$ in the cytoplasm, the net effect is an increased tau phosphorylation as indicated. 
of tau and its accumulation [32]. Manipulating PP2A had important consequences for kinase activities and tau phosphorylation, revealing both direct and indirect effects [33-35]. This dual role was supported by our studies in transgenic mice expressing dominant negative mutant forms of PP2A (see below) [36]. In determining the relative contributions of PP1, PP2A, PP2B, and PP5 (protein phosphatase 5) in the regulation of tau phosphorylation, all four phosphatases were found to dephosphorylate tau at Ser199, Ser202, Thr205, Thr212, Ser214, Ser235, Ser262, Ser396, Ser404, and Ser409, but with different efficiencies toward different sites [37]. PP2A, PP1, PP5, and PP2B account for approximately $71 \%, 11 \%, 10 \%$, and $7 \%$, respectively, of the total tau phosphatase activity in human brain [37].

An important finding was that hyperphosphorylated tau (AD-like phosphorylation status) sequesters normal tau into filaments and disassembles microtubules in vitro. Specifically it was shown that dephosphorylation with alkaline phosphatase abolished the ability of hyperphosphorylated tau to aggregate with normal tau and prevented NFT formation. Furthermore, hyperphosphorylated tau disassembled microtubules that were assembled from normal tau and tubulin [38]. This demonstrated on the one hand that fibrillar tau is toxic and secondly it underscored the importance of phosphorylation of tau in exerting this toxic effect. Hyperphosphorylated tau is glycosylated, and interestingly, although abnormal phosphorylation might promote aggregation of tau and inhibition of the assembly of microtubules, glycosylation appeared to be responsible for the maintenance of the PHF structure [39]. Of the tau sites required for microtubule binding, Ser262 and the AT180 epitope Thr231 seemed to be critical [40]. In causing neurodegeneration, a combined phosphorylation of tau at Thr212, Thr231, and Ser262 has been shown to cause neurodegeneration. We identified a role for several additional epitopes $[41,42]$, whereas work in Drosophila suggests that the extent of phosphorylation rather than phosphorylation of distinct sites is critical for tau to become toxic [43].

PP2A acts as a trimer composed of a catalytic subunit (PP2A $\mathrm{C} \alpha$ or $\mathrm{C} \beta$ ) and a scaffolding or structural subunit (PP2A A, PR65 $\alpha$, or PR65 $\beta$ ) that together form the core enzyme, and one of several regulatory subunits (PP2A B, e.g., B55 $\alpha$ ) [44] (Fig. 2B). Most regulatory subunits are present in brain where they reveal a distinct pattern of expression [45, 46]. More recently, Inge and colleagues became interested in endogenous inhibitors of PP2A, called I1(PP2A) and I2(PP2A) $\left(\mathrm{I}_{2}{ }^{\mathrm{PP} 2 \mathrm{~A}}\right)$ (Fig. 2D). By in situ hybridization analysis, they found a significant increase in neocortical levels of I1(PP2A) and I2(PP2A) in AD compared to control cases. Immunohistochemistry revealed that in $\mathrm{AD}$ tissue, I2(PP2A) was translocated from neuronal nuclei to the cytoplasm (Fig. 2D). Moreover, the 39 $\mathrm{kD}$ full-length $\mathrm{I}$ (PP2A) was found to be selectively cleaved into a $20 \mathrm{kD}$ fragment in AD brain cytosol [47]. When the C-terminal fragment of I2(PP2A) (termed $\mathrm{I}(2 \mathrm{CTF})$ ) was virally expressed in rat brains, this resulted in decreased PP2A activity, hyperphosphorylation of tau, and neurodegeneration. Furthermore, there was an increase in the level of activated glycogen synthase kinase-3 $\beta$, enhanced expression of intraneuronal $\mathrm{A} \beta$, and memory impairment in the injected animals [48]. Subsequent work by the team showed that both the amino- and the carboxy-terminal fragment of I2(PP2A) inhibited PP2A by binding to its catalytic subunit PP2A C, causing hyperphosphorylation of tau (Fig. 2D). They identified two critical residues, the carboxy-terminal acidic region and Val92 in the $\mathrm{N}$-terminal fragment as being essential for their association with PP2A C and the inhibition of the phosphatase activity [49].

$\mathrm{I} 2$ (PP2A) is an interesting molecule. It is also known under the name of SET (an oncogene) or as a truncated version of the chromatin remodeling factor Template Activating Factor (TAF1 $\beta$ ) [50]. SET/TAF1 $\beta$ is a coregulatory protein that binds to the estrogen receptor $\mathrm{ER} \alpha$ in vitro when the receptor is not complexed with an estrogen response element [51]. SET/TAF1 $\beta$ associates with an endogenous estrogen receptor-regulated gene, EB1, in the hypoacetylated transcriptionally inactive state but not with the hyperacetylated transcriptionally active form. SET/TAF1 $\beta$ specifically binds to unacetylated, hypoacetylated, and repressively marked histones but not to hyperacetylated histones. This suggested a role for SET/TAF1 $\beta$ as transducer of chromatin signaling by integrating chromatin hypoacetylation and transcriptional repression [52]. The linker histone $\mathrm{H} 1$ is a fundamental chromosomal protein involved in the maintenance of higher-ordered chromatin organization. SET/TAF1 $\beta$ is involved in the regulation of histone $\mathrm{H} 1$ dynamics in the nucleus, suggesting a role for the protein in histone-mediated chromatin assembly and disassembly [53]. The molecule is a positive regulator of apoptosis induced by a pro-apoptotic domain of the A $\beta P P$ cytoplasmic tail, Jcasp [54]. SET/TAF1 $\beta$ has been involved in a model of granzyme A-dependent cell death where it plays a protective role. In the latter model, SET/TAF1 $\beta$ is present mainly within a complex in the ER/Golgi, and this localization seems to be important for its protective 
effect [55]. This is in contrast to the observation that, in neurons, SET/TAF1 $\beta$ is primarily a nuclear protein $[54,56]$, in agreement with most of its known functions, and that apoptosis correlates with an increase in levels of cytoplasmic SET/TAF1 $\beta$.

Overall, several abnormalities of PP2A have been reported in $\mathrm{AD}$, including decreased $\mathrm{mRNA}$ and protein levels of PP2A C; decreased protein levels of the PP2A subunits A and B (B55 $\alpha)$; reduced PP2A C methylation at Leu309 due to impaired function of methyltransferase type IV; increased PP2A C phosphorylation at Tyr307; upregulation of the PP2A inhibitors I1 and 2 (SET/TAF1 $\beta$ ); and loss of enzymatic activity (Fig. 2C). A picture is emerging that in healthy neurons, $\mathrm{PP} 2 \mathrm{~A}$ is inactive in the nucleus and active in the cytoplasm as indicated, preventing tau phosphorylation. Under apoptotic or neurodegenerative conditions and as a consequence of ageing, nuclear pores start to leak and $\mathrm{I}^{\mathrm{PP} 2 \mathrm{~A}}$ relocalizes to the cytoplasm. Not only is $2^{\mathrm{PP} 2 \mathrm{~A}}$ cleaved into two smaller fragments that can now freely diffuse between the nucleus and cytoplasm, also, phosphorylation of $\mathrm{I}_{2}^{\mathrm{PP} 2 \mathrm{~A}}$ at $\operatorname{Ser}(\mathrm{S}) 9$ by CKII (casein kinase II) causes its retention in the cytoplasm [57]. Together with an increased activity of GSK3 $\beta$ in the cytoplasm, the net effect is an increased tau phosphorylation as shown in the schematic (Fig. 2D).

These observations indicate that PP2A and its many modes of regulation are suitable targets of therapeutic intervention in $\mathrm{AD}$ [58].

\section{PP2A TRANSGENIC AND KNOCKOUT MODELS}

After we had generated the first tau transgenic mouse model that presented with tau hyperphosphorylation and a somatodendritic localization of tau [59], we aimed to manipulate PP2A in mice, with the intention to learn more about the role of this enzyme in tau phosphorylation and NFT formation in vivo [5]. We first generated a complete knockout of the $\mathrm{C} \alpha$ subunit of PP2A, which leads to early embryonic lethality because one of the three germ layers, mesoderm, did not form [60]. Interestingly, despite a 97\% homology between the $C \alpha$ and the $C \beta$ subunit, the latter could not compensate for the absence of the former, due to a different subcellular localization in the developing embryo, with $\mathrm{C} \alpha$ being predominantly localized to the plasma membrane, and $\mathrm{C} \beta$ mainly to the cytoplasm and nucleus [61].

To address the role of tau phosphorylation in vivo, embryonic lethality had to be circumvented. Our first approach was to generate transgenic mouse strains that express dominant negative mutant forms of $\mathrm{C} \alpha$ under the control of a neuron-specific promoter (mThy1.2). In this we were guided by the identification of mutations in the catalytic subunit in yeast that were shown to fall into two principal categories [62]: (i) When they are introduced into the carboxy-terminus, a region known to modulate the binding of regulatory B subunits, the catalytic activity is unaffected, but either no or only a subset of heterotrimers are assembled (Fig. 2B); (ii) Mutations in the catalytic site of $\mathrm{C} \alpha$ either reduce or abolish the catalytic activity without affecting holoenzyme assembly. The expression of mutant $\mathrm{C} \alpha$ occurs at the expense of the endogenous $\mathrm{C} \alpha$ as the catalytic subunit is subject to a potent autoregulatory mechanism that keeps total levels of $\mathrm{C} \alpha$ constant [5]. We thus generated two transgenic mouse lines, Dom1 and Dom5, that represent these two categories [63, 64].

The catalytic subunit of PP2A is composed of 309 amino acids (Fig. 2C). Dom 1 mice express the L199P mutation that is in the catalytic core of PP2A C $\alpha$ in neurons. This caused a $34 \%$ chronically reduced activity of PP2A and a distinct pattern of phosphorylation (Ser202/Thr205 and Ser422), aggregation, and ubiquitination of endogenous tau protein, with endogenous tau accumulating in both the axonal and somatodendritic domain [63]. We subsequently found that chronic inhibition of PP2A in the Dom1 mice caused the activation of both ERK and JNK suggesting that the hyperphosphorylation of tau is mediated not only directly by reduced PP2A activity toward tau, but also indirectly by the activation of the ERK and JNK pathways [36].

The highly conserved DYFL motif in the carboxyterminus undergoes regulatory methylation at Leu309 and phosphorylation at Tyr307, with methylation causing an increase in activity and phosphorylation a decrease [44, 65] (Fig. 2C). The second strain established by us, Dom5, expresses L309A mutant PP2A C in neurons $[64,66]$. As in the Dom 1 mice, endogenous murine tau is hyperphosphorylated and translocated from the axon to the somatodendritic domain. In Dom5 mice, levels of the B subunits PR55 $\alpha$ and PR61 $\varepsilon$ are reduced by more than $50 \%$, while those of PR61 $\gamma$ and PR59 are significantly increased, indicating a major role for Leu309 of C $\alpha$ in PP2A holoenzyme composition in vivo (Fig. 2B,C). As endogenous mouse tau was hyperphosphorylated in these mice, the data further indicate that a reduction of PP2A holoenzymes containing B subunits such as PR55 $\alpha$ and PR61e is sufficient to cause tau phosphorylation [64]. Because PP2A C $\alpha$ L309A was also expressed in the Harderian 
(lacrimal) gland, postnatal development of the gland was affected causing hypoplasia and a slit-eye phenotype (enophthalmos) [66].

A second approach in circumventing embryonic lethality is gene targeting of regulatory B subunits. Altogether, there are not many knockout mouse strains available. Mice lacking PP2A subunit PR61/B' $\delta$ (Ppp2r5d) are viable without an obvious phenotype. The mice do, however, develop a spatially restricted tauopathy by deregulation of CDK5 and GSK3 $\beta$, demonstrating a complex network of interactions between PP2A and kinases [67]. In flies, knocking out the B' subunit caused elevated S6 kinase (S6K) phosphorylation, with the flies exhibiting phenotypes typical of elevated insulin signaling such as reduced total body triglycerides and reduced longevity [68]. A knock-out of the structural subunit A in mice confirmed that PP2A acts as a tumor suppressor [69].

To address the role of PP2A in mice with a preexisting tau pathology, we crossed the Dom5 strain with a second strain, pR5, that expresses P301L mutant tau, develops NFTs and displays an amygdala- and hippocampus-dependent behavioral impairment [70]. This exacerbated the tau pathology of pR5 mice significantly. The double-transgenic mice showed 7-fold increased numbers of hippocampal neurons that specifically phosphorylated the pathological Ser422 epitope of tau [71]. The mice showed 8-fold increased numbers of NFTs compared to pR5 mice, in agreement with our previous finding that NFT formation is correlated with and preceded by phosphorylation of tau at the Ser 422 epitope [72]. We further used the Dom5 mice to show that a small compound, sodium selenate, improved tau-dependent impairment and neurodegeneration in a PP2A-dependent manner [73].

\section{REFINEMENT: NON-CANONICAL FUNCTIONS OF TAU}

Most studies refer to tau as if it were one protein, confined to neurons and, in these, to axons where it binds to and stabilizes microtubules. Tau, however, exists in multiple isoforms and phosphorylation generates a plethora of species, both under physiological and pathological conditions, as reviewed by GrundkeIqbal and colleagues [74]. Tau is enriched in neurons, but it is not restricted to this cell-type and while it is in axons, it has been early on localized to other cellular compartments such as the nucleus $[75,76]$. A role for tau in this organelle has also been demonstrated for non-neuronal cells [77].
Interestingly, tau increases the melting temperature of DNA [78]. In vitro studies further revealed that purified tau binds to AT-rich sequences in the minor groove of DNA. By using an electrophoretic mobility shifting assay, it was shown that both the proline-rich domain and the microtubule-binding domain contributed to the interaction with DNA. Finally, DNA was protected from damage by free radicals when tau was present [79].

In taking this a step further, work in primary neuronal cultures suggested that tau has a role in the nucleus in protecting DNA from damage such as heat shock or oxidative stress [80]. This protective function was correlated with an increased binding of tau to DNA via the AT-rich minor groove. Interestingly, after inhibiting this interaction with the antibiotic netropsin, the unbound tau did not stay in the nuclear fraction. Whether shuttling tau into the nucleus requires specific cargo proteins remains to be determined. In being nuclearly localized, tau was found to be dephosphorylated whereas work by others implies that thermal and other forms of stress cause the opposite, i.e., hyperphosphorylation of tau [81].

By transcriptomic profiling, we identified the nuclear splicing factor SFPQ as being deregulated in tau mutant pR5 mice. We next found that in AD tissue, SFPQ was depleted from the nucleus and accumulated in the cytoplasm, and this was correlated with the Braak stage [82]. Notably, there is a growing list of transcription factors with an altered nucleo-cytoplasmic distribution in neurodegenerative disorders. Prominent examples are nuclear factorkappa B (NF-kB), activating transcription factor 2 (ATF2), TAR DNA binding protein 43 (TDP-43), p53, sma/mothers against decapentaplegic (Smad), E2 promoter binding factor 1 (E2F1), NRF2, and cyclic AMP response element-binding protein (CREB) [83]. Analysis of postmortem AD brain tissue showed increased cytoplasmic levels of ATF2 [84] and a reduced nuclear localization of NRF2 [85], cytoplasmic aggregates of pCREB and lack of nuclear pCREB in Parkinson's disease [86], and increased cytoplasmic:nuclear ratios of TDP-43 in frontotemporal dementia (FTD) and amyotrophic lateral sclerosis [87]. Together, these studies of a nucleo-cytoplasmic redistribution of nuclear proteins point at a putative role for transcription factors in a wide range of conditions with neurodegeneration [82]. In order to determine what the role of tau exactly is in non-axonal compartments such as the nucleus, however, more work needs to be done. Importantly, tau knockouts need to be consistently included as a control in these types of studies. 
In assessing the susceptibility of $A \beta$ plaque-forming mice to excitotoxic seizures, we identified a further role for tau in the dendrite [3]. Specifically, we found that phosphorylated tau has a role in targeting the tyrosine kinase Fyn to the dendrite where it phosphorylates the NMDA receptor which then recruits the scaffolding protein PSD-95 to form an excitotoxic complex. Crossing $A \beta$ plaque-forming mice onto a tau knockout background significantly reduced the susceptibility to excitotoxic seizures to a degree similar to what one achieves with the NMDA receptor antagonist MK801 [3]. When Grundke-Iqbal and colleagues induced excitotoxicity by intraperitoneal injection of wild-type mice with kainic acid, they found that this led to a transient dephosphorylation of tau within 6 hours postinjection, followed by sustained hyperphosphorylation of tau at multiple sites that are hyperphosphorylated in the AD brain. They speculated that the initial dephosphorylation of tau may result from an activation of PP2A, and that the sustained hyperphosphorylation may be mainly due to an activation of cdk5 and down-regulation of PP2A during the later phase [88]. Together this identifies a role for phosphorylated tau in various cellular processes, with functions other than the classical one of assembling and stabilizing microtubules [89].

\section{REFINEMENT: ROLE FOR DISTINCT TAU ISOFORMS}

As mentioned above, in many studies, tau is treated as one protein whereas in fact it is several proteins. Human tau is encoded by a single gene, $M A P T$, that is encoded on chromosome 17q21, spans $134 \mathrm{kbs}$ and contains 16 exons [90]. Aberrations in tau splicing regulation directly cause several neurodegenerative diseases [91]. There are two extended haplotypes, designated $\mathrm{H} 1$ and $\mathrm{H} 2$, with the latter having a genomic inversion [92]. The $\mathrm{H} 1$ haplotype is associated with some tauopathies including tanglepredominant dementia, and Parkinson's disease [93]. Recent work suggests that while $\mathrm{H} 1 / \mathrm{H} 2$ has been traditionally associated with differences in gene expression, the haplotype is more likely to operate by changing mRNA splicing in different brain regions [94].

Several low- and high-molecular-weight tau isoforms are generated by alternative splicing of 11 of the 16 exons [95]. In the human central nervous system, there are six low-molecular-weight tau isoforms ranging from 352 to 441 amino acids in length that are generated by alternative splicing of exons 2,3 , and 10
[96]. This results in isoforms that either have 0,1 , or 2 $\mathrm{N}$-terminal inserts $(0 \mathrm{~N}, 1 \mathrm{~N}$, and $2 \mathrm{~N})$, and either three (3R) or four (4R) microtubule binding domains [97]. Tau is developmentally regulated in humans, with the fetal isoform corresponding to the shortest of the six adult isoforms $[98,99]$. In adult brain tissue, the ratio of $3 \mathrm{R}$ to $4 \mathrm{R}$ isoforms is $1: 1$, which is also reflected by the ratio in the insoluble filaments of AD NFTs [100]. In contrast, in mice, there are only $4 \mathrm{R}$ isoforms in the adult brain while in the fetal brain the major isoform is 3R0N [101]. By using transgenic mice that express the entire human MAPT gene on an endogenous murine tau knockout background, developmental and species-specific variations in the expression of $3 R$ and $4 \mathrm{R}$ tau within the frontal cortex and hippocampus were observed. There were also differences in the subcellular distribution of these isoforms. Because the transgene is overexpressed, not surprisingly, the mice exhibited higher levels of neuronal cell body expression of tau compared to wild-type. Interestingly, however, expression of tau in the neuronal cell body was limited to the $3 \mathrm{R}$ isoform, whereas expression of 4R tau was more 'synaptic-like', with granular staining of the neuropil rather than in neuronal cell bodies [101].

The fact that there are different tau isoforms would suggest that they do have distinct biological functions. There are more studies available that investigate differences between $3 \mathrm{R}$ and $4 \mathrm{R}$ isoforms than the impact the presence of either one $(1 \mathrm{~N})$ or two $(2 \mathrm{~N})$ amino-terminal inserts has on tau function. In a pathological setting, a distortion of the $3 \mathrm{R}: 4 \mathrm{R}$ ratio causes FTD indicating that $3 R$ and $4 R$ tau must have different functions that likely also extend to normal conditions [102]. $4 \mathrm{R}$ isoforms interact with microtubules stronger than $3 \mathrm{R}$ and are more efficient at promoting microtubule assembly [103, 104]. Using video microscopy, it was discovered that $4 \mathrm{R}$ tau suppressed the shortening rate, whereas 3R tau had little or no detectable effect. Similarly, $3 \mathrm{R}$ tau had no effect on the length shortened during a shortening event, whereas $4 \mathrm{R}$ tau strongly reduced this parameter [104]. What discriminates $3 \mathrm{R}(\mathrm{R} 1 / \mathrm{R} 3 / \mathrm{R} 4)$ from $4 \mathrm{R}(\mathrm{R} 1 / \mathrm{R} 2 / \mathrm{R} 3 / \mathrm{R} 4)$ tau is the second repeat $(\mathrm{R} 2)$ encoded by exon 10 . When the inter-repeat region between R1 and R2 is looked at in more detail one finds that this represents a unique microtubule-binding site, with more than twice the binding affinity of any individual repeat [105]. Subsequent work showed that $3 \mathrm{R}$ tau possesses a core of microtubule binding activity residing within the first two repeats and their intervening inter-repeat. Within this core, specific sequence elements and spacing are essential for proper function. 
Furthermore, the carboxy-terminal sequences flanking the core microtubule binding unit in $3 \mathrm{R}$ tau were found to strongly enhance the microtubule binding affinity of the core unit [106]. For tau aggregation, by NMR, two hexapeptides at the beginning of the second and third repeats $\left({ }^{275}\right.$ VQIINK ${ }^{280}$ and ${ }^{306}$ VQIVYK $\left.^{311}\right)$ are crucial; of these ${ }^{275}$ VQIINK ${ }^{280}$ is located in the second repeat that discriminates $3 R$ from $4 R$ tau [107]. When the aggregation kinetics of the six human tau isoforms was examined in vitro using electron microscopy assay methods, it was found that segments encoded by exons 2 and 10 promoted aggregation, whereas the segment encoded by exon 3 depressed it, with its efficacy dependent on the presence or absence of a fourth microtubule binding repeat [108].

In a very comprehensive study, 2,011 brain samples originating from 439 individuals were analyzed to obtain information on the regional expression, splicing, and regulation of MAPT [94]. It was firstly found that there is a significant regional variation in mRNA expression and splicing of MAPT within the human brain. Furthermore, at the gene level, the regional distribution of mRNA expression and total tau protein expression levels were largely in agreement, appearing to be highly correlated. The frontal cortex was the region with the highest $M A P T$ expression. At the protein level, the frontal cortex had also the highest tau levels followed by the occipital cortex, white matter, putamen and eventually, cerebellum. When the interaction of tau and the Src kinase Fyn (more on this below) was investigated in vitro by surface plasmon resonance, the interaction of the SH3 domain of Fyn with $3 \mathrm{R}$ tau was found to be 20-fold stronger than that with 4R tau [109]. Whether this is also the case in vivo remains to be determined.

What about the role of the amino-terminus and the two alternatively spliced exons that in the adult mouse brain differentiates the three $4 \mathrm{R}$ tau isoforms? Early studies showed that the amino-terminal domain (also known as projection domain) is able to mediate interactions between tau and the plasma membrane in a phosphorylation-dependent manner [110, 111]. When we expressed the projection domain of tau $(\Delta \mathrm{Tau})$ in neurons of transgenic mice, $\Delta$ Tau was localized to the membrane as indicated by co-immunostaining with cadherin and subcellular fractionation of membranes [3]. Interestingly, $\Delta$ Tau was localized to the soma and excluded from dendrites. $\Delta$ Tau also localized to axons, although it lacked a microtubule binding domain. This localization was not achieved by a hitchhiker mechanism as $\Delta$ Tau entered the axons even in the absence of endogenous, full-length tau [3]. The amino-terminus of tau interacts via its seventh PXXP motif with the SH3 domain of Fyn and other Src kinases [3, 112]; tau phosphorylated at Tyr18 interacts with the $\mathrm{SH} 2$ domain of Fyn [113]. How phosphorylation of tau at sites other than Tyr18 (i.e., how serine and threonine phosphorylation) affects this interaction, especially in an in vivo setting, is only partly understood. An interaction of Fyn and tau is also critical in oligodendrocytes where tau has a key role in myelination [114].

In the context of the recent findings of tau release into the interstitial space and what has been termed spreading [115], it was found that tau isoforms influence the rate of tau release, whereby the aminoterminus (exons 2/3) and the length of the microtubule binding repeat contribute to tau release from the cell [116]. Cells expressing 2N3R tau exhibited the highest ratio of secretion (ratio of extracellular/intracellular tau), and 2N4R the lowest. Cells expressing tau isoforms that do not contain the $\mathrm{N}$-terminal exons 2 and $3(0 N 3 R$ and $0 \mathrm{~N} 4 \mathrm{R})$ had a similar ratio of extracellular/intracellular tau, which is significantly lower than for $2 \mathrm{~N} 3 \mathrm{R}$ and significantly higher than for $2 \mathrm{~N} 4 \mathrm{R}$. These findings strongly indicate that the amino terminal domain of tau has an important role in neurodegenerative disorders. As mentioned above, segments encoded by exons 2 (and 10) promote tau aggregation, whereas the segment encoded by exon 3 depresses it [108]. Together this demonstrates a crucial role of the amino-terminus in tau aggregation, spreading, dendritic localization and signaling, however, information on the distribution of all tau isoforms and a detailed insight into their function in a physiological setting is still lacking.

\section{OUTLOOK}

It is now almost four decades ago since Inge Grundke-Iqbal published her first paper on tau. Since then the field has developed enormously and tau is now on par with $A \beta$, a peptide with which it performs a toxic pas de deux in $\mathrm{AD}$ [117]. It is more and more appreciated that tau is an important drug target in its own right and an increasing number of clinical trials targets tau, in addition to $A \beta$ [118]. Vaccination trials have only been pursued targeting $A \beta$, however, it is only a matter of time until tau vaccinations will enter clinical trials [119]. Work by Inge and others would suggest that in addition to tau, its major phosphatase, $\mathrm{PP} 2 \mathrm{~A}$, is an equally attractive drug target, and not surprisingly the PP2A agonist sodium selenate, a compound shown to ameliorate the tau 
pathology in tau mutant mice in a PP2A-dependent manner [73], has just entered a phase 2A clinical trial in mild to moderate AD (https://www.anzctr.org.au/Trial/ Registration/TrialReview.aspx?ACTRN=1261100120 0976). Together, we feel that the best tribute would be paid to Inge and her work by furthering tau research by better understanding its diverse role in a physiological context and by understanding how its dysregulation causes neurodegeneration and dementia.

\section{ACKNOWLEDGMENTS}

This study was supported by the Estate of Dr. Clem Jones AO and by grants from the Australian Research Council and the National Health and Medical Research Council of Australia to JG.

Authors' disclosures available online (http://www.jalz.com/disclosures/view.php?id=1772).

\section{REFERENCES}

[1] Iqbal K, Tellez-Nagel I, Grundke-Iqbal I (1974) Protein abnormalities in Huntington's chorea. Brain Res 76, 178184.

[2] Iqbal K, Wisniewski HM, Grundke-Iqbal I, Korthals JK, Terry RD (1975) Chemical pathology of neurofibrils Neurofibrillary tangles of Alzheimer's presenile-senile dementia. J Histochem Cytochem 23, 563-569.

[3] Ittner LM, Ke YD, Delerue F, Bi M, Gladbach A, van Eersel J, Wolfing H, Chieng BC, Christie MJ, Napier IA, Eckert A, Staufenbiel M, Hardeman E, Götz J (2010) Dendritic function of tau mediates amyloid-beta toxicity in Alzheimer's disease mouse models. Cell 142, 387-397.

[4] Iqbal K, Wang X, Blanchard J, Liu F, Gong CX, Grundke-Iqbal I (2010) Alzheimer's disease neurofibrillary degeneration: Pivotal and multifactorial. Biochem Soc Trans 38, 962-966.

[5] Götz J, Schild A (2003) Transgenic and knockout models of PP2A. Methods Enzymol 366, 390-403.

[6] Iqbal K, Grundke-Iqbal I (2006) Discoveries of tau, abnormally hyperphosphorylated tau and others of neurofibrillary degeneration: A personal historical perspective. J Alzheimers Dis 9, 219-242.

[7] Weingarten MD, Lockwood AH, Hwo SY, Kirschner MW (1975) A protein factor essential for microtubule assembly. Proc Natl Acad Sci U S A 72, 1858-1862.

[8] Dehmelt L, Halpain S (2005) The MAP2/Tau family of microtubule-associated proteins. Genome Biol 6, 204.

[9] Al-Bassam J, Ozer RS, Safer D, Halpain S, Milligan RA (2002) MAP2 and tau bind longitudinally along the outer ridges of microtubule protofilaments. J Cell Biol 157, 11871196.

[10] Magnani E, Fan J, Gasparini L, Golding M, Williams M, Schiavo G, Goedert M, Amos LA, Spillantini MG (2007) Interaction of tau protein with the dynactin complex. $E M B O$ $J$ 26, 4546-4554.

[11] Brion JP, Passareiro H, Nunez J, Flament-Durand D (1985) Mise en évidence de la protéine Tau au niveau des lésions de dégénérescence neurofibrillaire de la maladie d'Alzheimer. Arch Biol (Bruxelles) 95, 229-235.

[12] Kosik KS, Joachim CL, Selkoe DJ (1986) Microtubuleassociated protein tau (tau) is a major antigenic component of paired helical filaments in Alzheimer disease. Proc Natl Acad Sci U S A 83, 4044-4048.

[13] Delacourte A, Defossez A (1986) Alzheimer's disease: Tau proteins, the promoting factors of microtubule assembly, are major components of paired helical filaments. J Neurol Sci 76, 173-186.

[14] Nukina N, Ihara Y (1986) One of the antigenic determinants of paired helical filaments is related to tau protein. J Biochem 99, 1541-1544

[15] Grundke-Iqbal I, Iqbal K, Quinlan M, Tung YC, Zaidi MS, Wisniewski HM (1986) Microtubule-associated protein tau A component of Alzheimer paired helical filaments. J Biol Chem 261, 6084-6089.

[16] Wood JG, Mirra SS, Pollock NJ, Binder LI (1986) Neurofibrillary tangles of Alzheimer disease share antigenic determinants with the axonal microtubule-associated protein tau (tau). Proc Natl Acad Sci U S A 83, 4040-4043.

[17] Wolozin BL, Pruchnicki A, Dickson DW, Davies P (1986) A neuronal antigen in the brains of Alzheimer patients. Science 232, 648-650.

[18] Wischik CM, Crowther RA, Stewart M, Roth M (1985) Subunit structure of paired helical filaments in Alzheimer's disease. J Cell Biol 100, 1905-1912.

[19] Pierre M, Nunez J (1983) Multisite phosphorylation of tau proteins from rat brain. Biochem Biophys Res Commun 115, 212-219.

[20] Lindwall G, Cole RD (1984) Phosphorylation affects the ability of tau protein to promote microtubule assembly. J Biol Chem 259, 5301-5305.

[21] Grundke-Iqbal I, Iqbal K, Tung YC, Quinlan M, Wisniewski HM, Binder LI (1986) Abnormal phosphorylation of the microtubule-associated protein tau (tau) in Alzheimer cytoskeletal pathology. Proc Natl Acad Sci U S A 83, 49134917.

[22] Ihara Y, Nukina N, Miura R, Ogawara M (1986) Phosphorylated tau protein is integrated into paired helical filaments in Alzheimer's disease. J Biochem (Tokyo) 99, 1807-1810.

[23] Bancher C, Brunner C, Lassmann H, Budka H, Jellinger K, Wiche G, Seitelberger F, Grundke-Iqbal I, Iqbal K, Wisniewski HM (1989) Accumulation of abnormally phosphorylated tau precedes the formation of neurofibrillary tangles in Alzheimer's disease. Brain Res 477, 90-99.

[24] Goto S, Yamamoto H, Fukunaga K, Iwasa T, Matsukado Y, Miyamoto E (1985) Dephosphorylation of microtubuleassociated protein 2 , tau factor, and tubulin by calcineurin. J Neurochem 45, 276-283.

[25] Yamamoto H, Saitoh Y, Fukunaga K, Nishimura H, Miyamoto E (1988) Dephosphorylation of microtubule proteins by brain protein phosphatases 1 and $2 \mathrm{~A}$, and its effect on microtubule assembly. J Neurochem 50, 1614-1623.

[26] Hoshi M, Nishida E, Miyata Y, Sakai H, Miyoshi T, Ogawara H, Akiyama T (1987) Protein kinase C phosphorylates tau and induces its functional alterations. FEBS Lett 217, 237241.

[27] Baudier J, Cole RD (1987) Phosphorylation of tau proteins to a state like that in Alzheimer's brain is catalyzed by a calcium/calmodulin-dependent kinase and modulated by phospholipids. J Biol Chem 262, 17577-17583.

[28] Hoshi M, Nishida E, Sakai H (1989) Characterization of a mitogen-activated, $\mathrm{Ca} 2+$-sensitive microtubule-associated protein-2 kinase. Eur J Biochem 184, 477-486. 
[29] Bancher C, Grundke-Iqbal I, Iqbal K, Fried VA, Smith HT, Wisniewski HM (1991) Abnormal phosphorylation of tau precedes ubiquitination in neurofibrillary pathology of Alzheimer disease. Brain Res 539, 11-18.

[30] Gong CX, Singh TJ, Grundke-Iqbal I, Iqbal K (1993) Phosphoprotein phosphatase activities in Alzheimer disease brain. J Neurochem 61, 921-927.

[31] Gong CX, Grundke-Iqbal I, Damuni Z, Iqbal K (1994) Dephosphorylation of microtubule-associated protein tau by protein phosphatase-1 and $-2 \mathrm{C}$ and its implication in Alzheimer disease. FEBS Lett 341, 94-98.

[32] Gong CX, Lidsky T, Wegiel J, Zuck L, Grundke-Iqbal I, Iqbal K (2000) Phosphorylation of microtubule-associated protein tau is regulated by protein phosphatase $2 \mathrm{~A}$ in mammalian brain Implications for neurofibrillary degeneration in Alzheimer's disease. J Biol Chem 275, 5535-5544.

[33] Bennecib M, Gong CX, Grundke-Iqbal I, Iqbal K (2000) Role of protein phosphatase-2A and -1 in the regulation of GSK-3, cdk5 and cdc2 and the phosphorylation of tau in rat forebrain. FEBS Lett 485, 87-93.

[34] Bennecib M, Gong CX, Grundke-Iqbal I, Iqbal K (2001) Inhibition of PP-2A upregulates CaMKII in rat forebrain and induces hyperphosphorylation of tau at Ser 262/356. FEBS Lett 490, 15-22.

[35] Pei JJ, Gong CX, An WL, Winblad B, Cowburn RF, Grundke-Iqbal I, Iqbal K (2003) Okadaic-acid-induced inhibition of protein phosphatase $2 \mathrm{~A}$ produces activation of mitogen-activated protein kinases ERK1/2, MEK1/2, and p70 S6, similar to that in Alzheimer's disease. Am J Pathol 163, 845-858.

[36] Kins S, Kurosinski P, Nitsch RM, Götz J (2003) Activation of the ERK and JNK signaling pathways caused by neuron specific inhibition of PP2A in transgenic mice. Am J Pathol 163, 833-843.

[37] Liu F, Grundke-Iqbal I, Iqbal K, Gong CX (2005) Contributions of protein phosphatases PP1, PP2A, PP2B and PP5 to the regulation of tau phosphorylation. Eur J Neurosci 22, 1942-1950.

[38] Alonso AC, Grundke-Iqbal I, Iqbal K (1996) Alzheimer's disease hyperphosphorylated tau sequesters normal tau into tangles of filaments and disassembles microtubules. Nat Med 2, 783-787.

[39] Wang JZ, Grundke-Iqbal I, Iqbal K (1996) Glycosylation of microtubule-associated protein tau: An abnormal posttranslational modification in Alzheimer's disease. Nat Med 2, 871-875.

[40] Sengupta A, Kabat J, Novak M, Wu Q, Grundke-Iqbal I, Iqbal K (1998) Phosphorylation of tau at both Thr 231 and Ser 262 is required for maximal inhibition of its binding to microtubules. Arch Biochem Biophys 357, 299-309.

[41] Ferrari A, Hoerndli F, Baechi T, Nitsch RM, Götz J (2003) Beta-amyloid induces PHF-like tau filaments in tissue culture. J Biol Chem 278, 40162-40168.

[42] Pennanen L, Götz J (2005) Different tau epitopes define Abeta(42)-mediated tau insolubility. Biochem Biophys Res Commun 337, 1097-1101.

[43] Steinhilb ML, Dias-Santagata D, Fulga TA, Felch DL, Feany MB (2007) Tau phosphorylation sites work in concert to promote neurotoxicity in vivo. Mol Biol Cell 18, 5060-5068.

[44] Janssens V, Longin S, Goris J (2008) PP2A holoenzyme assembly: In cauda venenum (the sting is in the tail). Trends Biochem Sci 33, 113-121.

[45] Schmidt K, Kins S, Schild A, Nitsch RM, Hemmings BA, Götz J (2002) Diversity, developmental regulation and dis- tribution of murine PR55/B subunits of protein phosphatase 2A. Eur J Neurosci 16, 2039-2048.

[46] Martens E, Stevens S, Janssens J, Götz J, Goris J, van Hoof C (2004) Genomic organisation, chromosomal localisation, tissue distribution and developmental regulation of the PR61/B' regulatory subunits of protein phosphatase 2A in mice. J Mol Biol 336, 971-986.

[47] Tanimukai H, Grundke-Iqbal I, Iqbal K (2005) Upregulation of inhibitors of protein phosphatase-2A in Alzheimer's disease. Am J Pathol 166, 1761-1771.

[48] Wang X, Blanchard J, Kohlbrenner E, Clement N, Linden RM, Radu A, Grundke-Iqbal I, Iqbal K (2010) The carboxyterminal fragment of inhibitor-2 of protein phosphatase-2A induces Alzheimer disease pathology and cognitive impairment. FASEB J 24, 4420-4432.

[49] Arnaud L, Chen S, Liu F, Li B, Khatoon S, GrundkeIqbal I, Iqbal K (2011) Mechanism of inhibition of PP2A activity and abnormal hyperphosphorylation of tau by I2(PP2A)/SET. FEBS Lett 585, 2653-2659.

[50] Saito S, Miyaji-Yamaguchi M, Shimoyama T, Nagata K (1999) Functional domains of template-activating factor-I as a protein phosphatase $2 \mathrm{~A}$ inhibitor. Biochem Biophys Res Commun 259, 471-475.

[51] Loven MA, Muster N, Yates JR, Nardulli AM (2003) A novel estrogen receptor alpha-associated protein, template-activating factor Ibeta, inhibits acetylation and transactivation. Mol Endocrinol 17, 67-78.

[52] Kutney SN, Hong R, Macfarlan T, Chakravarti D (2004) A signaling role of histone-binding proteins and INHAT subunits pp32 and Set/TAF-Ibeta in integrating chromatin hypoacetylation and transcriptional repression. J Biol Chem 279, 30850-30855.

[53] Kato K, Okuwaki M, Nagata K (2011) Role of Template Activating Factor-I as a chaperone in linker histone dynamics. J Cell Sci 124, 3254-3265.

[54] Madeira A, Pommet JM, Prochiantz A, Allinquant B (2005) SET protein (TAF1beta, I2PP2A) is involved in neuronal apoptosis induced by an amyloid precursor protein cytoplasmic subdomain. FASEB J 19, 1905-1907.

[55] Fan Z, Beresford PJ, Oh DY, Zhang D, Lieberman J (2003) Tumor suppressor NM23-H1 is a granzyme A-activated DNase during CTL-mediated apoptosis, and the nucleosome assembly protein SET is its inhibitor. Cell 112, 659-672.

[56] Qu D, Li Q, Lim HY, Cheung NS, Li R, Wang JH, Qi RZ (2002) The protein SET binds the neuronal Cdk5 activator p35nck5a and modulates Cdk5/p35nck5a activity. $J$ Biol Chem 277, 7324-7332.

[57] Yu G, Yan T, Feng Y, Liu X, Xia Y, Luo H, Wang JZ, Wang X (2013) Ser9 phosphorylation causes cytoplasmic detention of I2(PP2A)/SET in Alzheimer disease. Neurobiol Aging 34, 1748-1758.

[58] Torrent L, Ferrer I (2012) PP2A and Alzheimer disease. Curr Alzheimer Res 9, 248-256.

[59] Götz J, Probst A, Spillantini MG, Schafer T, Jakes R, Burki K, Goedert M (1995) Somatodendritic localization and hyperphosphorylation of tau protein in transgenic mice expressing the longest human brain tau isoform. EMBO J 14, 1304-1313.

[60] Götz J, Probst A, Ehler E, Hemmings B, Kues W (1998) Delayed embryonic lethality in mice lacking protein phosphatase 2A catalytic subunit Calpha. Proc Natl Acad Sci U S A 95, 12370-12375.

[61] Götz J, Probst A, Mistl C, Nitsch RM, Ehler E (2000) Distinct role of protein phosphatase $2 \mathrm{~A}$ subunit calpha in the 
regulation of E-cadherin and beta-catenin during development. Mech Dev 93, 83-93.

[62] Evans DR, Myles T, Hofsteenge J, Hemmings BA (1999) Functional expression of human PP2Ac in yeast permits the identification of novel C-terminal and dominant-negative mutant forms. J Biol Chem 274, 24038-24046.

[63] Kins S, Crameri A, Evans DR, Hemmings BA, Nitsch RM, Götz J (2001) Reduced PP2A activity induces hyperphosphorylation and altered compartmentalization of tau in transgenic mice. J Biol Chem 276, 38193-38200.

[64] Schild A, Ittner LM, Götz J (2006) Altered phosphorylation of cytoskeletal proteins in mutant protein phosphatase $2 \mathrm{~A}$ transgenic mice. Biochem Biophys Res Commun 343, 11711178.

[65] Bryant JC, Westphal RS, Wadzinski BE (1999) Methylated C-terminal leucine residue of PP2A catalytic subunit is important for binding of regulatory Balpha subunit. Biochem $J 339$ (Pt 2), 241-246.

[66] Schild A, Isenmann S, Tanimoto N, Tonagel F, Seeliger MW, Ittner LM, Kretz A, Ogris E, Götz J (2006) Impaired development of the Harderian gland in mutant protein phosphatase 2A transgenic mice. Mech Dev 123, 362-371.

[67] Louis JV, Martens E, Borghgraef P, Lambrecht C, Sents W, Longin S, Zwaenepoel K, Pijnenborg R, Landrieu I, Lippens G, Ledermann B, Götz J, Van Leuven F, Goris J, Janssens V (2011) Mice lacking phosphatase PP2A subunit PR61/B'delta (Ppp2r5d) develop spatially restricted tauopathy by deregulation of CDK5 and GSK3beta. Proc Natl Acad Sci U S A 108, 6957-6962.

[68] Hahn K, Miranda M, Francis VA, Vendrell J, Zorzano A, Teleman AA (2010) PP2A regulatory subunit PP2AB' counteracts S6K phosphorylation. Cell Metab 11, 438444.

[69] Ruediger R, Ruiz J, Walter G (2011) Human cancerassociated mutations in the Aalpha subunit of protein phosphatase $2 \mathrm{~A}$ increase lung cancer incidence in Aalpha knock-in and knockout mice. Mol Cell Biol 31, 3832-3844.

[70] Pennanen L, Wolfer DP, Nitsch RM, Götz J (2006) Impaired spatial reference memory and increased exploratory behavior in P301L tau transgenic mice. Genes Brain Behav 5, 369-379.

[71] Deters N, Ittner LM, Götz J (2009) Substrate-specific reduction of PP2A activity exaggerates tau pathology. Biochem Biophys Res Commun 379, 400-405.

[72] Gotz J, Chen F, van Dorpe J, Nitsch RM (2001) Formation of neurofibrillary tangles in P3011 tau transgenic mice induced by Abeta 42 fibrils. Science 293, 1491-1495.

[73] van Eersel J, Ke YD, Liu X, Delerue F, Kril JJ, Götz J, Ittner LM (2010) Sodium selenate mitigates tau pathology, neurodegeneration, and functional deficits in Alzheimer's disease models. Proc Natl Acad Sci U S A 107, 13888-13893.

[74] Wang JZ, Xia YY, Grundke-Iqbal I, Iqbal K (2013) Abnormal hyperphosphorylation of tau: Sites, regulation, and molecular mechanism of neurofibrillary degeneration. $J$ Alzheimers Dis 33(Suppl 1), S123-S139.

[75] Loomis PA, Howard TH, Castleberry RP, Binder LI (1990) Identification of nuclear tau isoforms in human neuroblastoma cells. Proc Natl Acad Sci U S A 87, 8422-8426.

[76] Brady RM, Zinkowski RP, Binder LI (1995) Presence of tau in isolated nuclei from human brain. Neurobiol Aging $\mathbf{1 6}$ 479-486.

[77] Cross DC, Munoz JP, Hernandez P, Maccioni RB (2000) Nuclear and cytoplasmic tau proteins from human nonneuronal cells share common structural and functional features with brain tau. J Cell Biochem 78, 305-317.
[78] Hua Q, He RQ (2003) Tau could protect DNA double helix structure. Biochim Biophys Acta 1645, 205-211.

[79] Wei Y, Qu MH, Wang XS, Chen L, Wang DL, Liu Y, Hua Q, He RQ (2008) Binding to the minor groove of the double-strand, tau protein prevents DNA from damage by peroxidation. PLoS One 3, e2600.

[80] Sultan A, Nesslany F, Violet M, Begard S, Loyens A, Talahari S, Mansuroglu Z, Marzin D, Sergeant N, Humez S, Colin M, Bonnefoy E, Buee L, Galas MC (2011) Nuclear tau, a key player in neuronal DNA protection. $\mathrm{J}$ Biol Chem 286, 4566-4575.

[81] Bretteville A, Marcouiller F, Julien C, El Khoury NB, Petry FR, Poitras I, Mouginot D, Levesque G, Hebert SS, Planel E (2012) Hypothermia-induced hyperphosphorylation: A new model to study tau kinase inhibitors. Sci Rep 2, 480.

[82] Ke Y, Dramiga J, Schutz U, Kril JJ, Ittner LM, Schroder H, Götz J (2012) Tau-Mediated Nuclear Depletion and Cytoplasmic Accumulation of SFPQ in Alzheimer's and Pick's Disease. PLoS One 7, e35678.

[83] Chu CT, Plowey ED, Wang Y, Patel V, Jordan-Sciutto KL (2007) Location, location, location: Altered transcription factor trafficking in neurodegeneration. $J$ Neuropathol Exp Neurol 66, 873-883.

[84] Yamada T, Yoshiyama Y, Kawaguchi N (1997) Expression of activating transcription factor-2 (ATF-2), one of the cyclic AMP response element (CRE) binding proteins, in Alzheimer disease and non-neurological brain tissues. Brain Res 749, 329-334.

[85] Ramsey CP, Glass CA, Montgomery MB, Lindl KA, Ritson GP, Chia LA, Hamilton RL, Chu CT, Jordan-Sciutto KL (2007) Expression of Nrf2 in neurodegenerative diseases. J Neuropathol Exp Neurol 66, 75-85.

[86] Chalovich EM, Zhu JH, Caltagarone J, Bowser R, Chu CT (2006) Functional repression of cAMP response element in 6-hydroxydopamine-treated neuronal cells. $J$ Biol Chem 281, 17870-17881.

[87] Neumann M, Sampathu DM, Kwong LK, Truax AC, Micsenyi MC, Chou TT, Bruce J, Schuck T, Grossman M, Clark CM, McCluskey LF, Miller BL, Masliah E, Mackenzie IR, Feldman H, Feiden W, Kretzschmar HA, Trojanowski JQ, Lee VM (2006) Ubiquitinated TDP-43 in frontotemporal lobar degeneration and amyotrophic lateral sclerosis. Science 314, 130-133.

[88] Liang Z, Liu F, Iqbal K, Grundke-Iqbal I, Gong CX (2009) Dysregulation of tau phosphorylation in mouse brain during excitotoxic damage. J Alzheimers Dis 17, 531-539.

[89] Gustke N, Trinczek B, Biernat J, Mandelkow EM, Mandelkow E (1994) Domains of tau protein and interactions with microtubules. Biochemistry (Mosc) 33, 9511-9522.

[90] Neve RL, Harris P, Kosik KS, Kurnit DM, Donlon TA (1986) Identification of cDNA clones for the human microtubuleassociated protein tau and chromosomal localization of the genes for tau and microtubule-associated protein 2. Brain Res 387, 271-280.

[91] Andreadis A (2012) Tau splicing and the intricacies of dementia. J Cell Physiol 227, 1220-1225.

[92] Baker M, Litvan I, Houlden H, Adamson J, Dickson D, Perez-Tur J, Hardy J, Lynch T, Bigio E, Hutton M (1999) Association of an extended haplotype in the tau gene with progressive supranuclear palsy. Hum Mol Genet 8, 711715.

[93] Santa-Maria I, Haggiagi A, Liu X, Wasserscheid J, Nelson PT, Dewar K, Clark LN, Crary JF (2012) The MAPT H1 haplotype is associated with tangle-predominant dementia. Acta Neuropathol 124, 693-704. 
[94] Trabzuni D, Wray S, Vandrovcova J, Ramasamy A, Walker R, Smith C, Luk C, Gibbs JR, Dillman A, Hernandez DG, Arepalli S, Singleton AB, Cookson MR, Pittman AM, de Silva R, Weale ME, Hardy J, Ryten M (2012) MAPT expression and splicing is differentially regulated by brain region: Relation to genotype and implication for tauopathies. Hum Mol Genet 21, 4094-4103.

[95] Goedert M, Wischik CM, Crowther RA, Walker JE, Klug A (1988) Cloning and sequencing of the cDNA encoding a core protein of the paired helical filament of Alzheimer disease: Identification as the microtubule-associated protein tau. Proc Natl Acad Sci U S A 85, 4051-4055.

[96] Goedert M, Spillantini MG, Jakes R, Rutherford D, Crowther RA (1989) Multiple isoforms of human microtubule-associated protein tau: Sequences and localization in neurofibrillary tangles of Alzheimer's disease. Neuron 3, 519-526.

[97] Goedert M, Spillantini MG, Potier MC, Ulrich J, Crowther RA (1989) Cloning and sequencing of the cDNA encoding an isoform of microtubule-associated protein tau containing four tandem repeats: Differential expression of tau protein mRNAs in human brain. EMBO J 8, 393-399.

[98] Goedert M, Jakes R, Crowther RA, Six J, Lubke U, Vandermeeren M, Cras P, Trojanowski JQ, Lee VM (1993) The abnormal phosphorylation of tau protein at Ser-202 in Alzheimer disease recapitulates phosphorylation during development. Proc Natl Acad Sci U S A 90, 5066-5070.

[99] Brion JP, Smith C, Couck AM, Gallo JM, Anderton BH (1993) Developmental changes in tau phosphorylation: Fetal tau is transiently phosphorylated in a manner similar to paired helical filament-tau characteristic of Alzheimer's disease. J Neurochem 61, 2071-2080.

[100] Hong M, Zhukareva V, Vogelsberg-Ragaglia V, Wszolek Z, Reed L, Miller BI, Geschwind DH, Bird TD, McKeel D, Goate A, Morris JC, Wilhelmsen KC, Schellenberg GD, Trojanowski JQ, Lee VM (1998) Mutation-specific functional impairments in distinct tau isoforms of hereditary FTDP-17. Science 282, 1914-1917.

[101] McMillan P, Korvatska E, Poorkaj P, Evstafjeva Z, Robinson L, Greenup L, Leverenz J, Schellenberg GD, D’Souza I (2008) Tau isoform regulation is region- and cell-specific in mouse brain. J Comp Neurol 511, 788-803.

[102] Ingelsson M, Ramasamy K, Russ C, Freeman SH, Orne J, Raju S, Matsui T, Growdon JH, Frosch MP, Ghetti B, Brown RH, Irizarry MC, Hyman BT (2007) Increase in the relative expression of tau with four microtubule binding repeat regions in frontotemporal lobar degeneration and progressive supranuclear palsy brains. Acta Neuropathol 114, 471-479.

[103] Lee G, Neve RL, Kosik KS (1989) The microtubule binding domain of tau protein. Neuron 2, 1615-1624.

[104] Panda D, Samuel JC, Massie M, Feinstein SC, Wilson L (2003) Differential regulation of microtubule dynamics by three- and four-repeat tau: Implications for the onset of neurodegenerative disease. Proc Natl Acad Sci U S A $\mathbf{1 0 0}$, 9548-9553.
[105] Goode BL, Feinstein SC (1994) Identification of a novel microtubule binding and assembly domain in the developmentally regulated inter-repeat region of tau. J Cell Biol 124, 769-782.

[106] Goode BL, Chau M, Denis PE, Feinstein SC (2000) Structural and functional differences between 3-repeat and 4-repeat tau isoforms. Implications for normal tau function and the onset of neurodegenetative disease. J Biol Chem $\mathbf{2 7 5}$, 38182-38189.

[107] von Bergen M, Barghorn S, Li L, Marx A, Biernat J, Mandelkow EM, Mandelkow E (2001) Mutations of tau protein in frontotemporal dementia promote aggregation of paired helical filaments by enhancing local beta-structure. J Biol Chem 276, 48165-48174.

[108] Zhong Q, Congdon EE, Nagaraja HN, Kuret J (2012) Tau isoform composition influences rate and extent of filament formation. J Biol Chem 287, 20711-20719.

[109] Bhaskar K, Yen SH, Lee G (2005) Disease-related modifications in tau affect the interaction between Fyn and Tau. J Biol Chem 280, 35119-35125.

[110] Brandt R, Leger J, Lee G (1995) Interaction of tau with the neural plasma membrane mediated by tau's amino-terminal projection domain. J Cell Biol 131, 1327-1340.

[111] Maas T, Eidenmuller J, Brandt R (2000) Interaction of tau with the neural membrane cortex is regulated by phosphorylation at sites that are modified in paired helical filaments. J Biol Chem 275, 15733-15740.

[112] Lee G, Newman ST, Gard DL, Band H, Panchamoorthy G (1998) Tau interacts with src-family non-receptor tyrosine kinases. J Cell Sci 111, 3167-3177.

[113] Lee G, Thangavel R, Sharma VM, Litersky JM, Bhaskar K, Fang SM, Do LH, Andreadis A, Van Hoesen G, Ksiezak-Reding H (2004) Phosphorylation of tau by fyn: Implications for Alzheimer's disease. J Neurosci 24, 23042312.

[114] Belkadi A, LoPresti P (2008) Truncated tau with the Fyn-binding domain and without the microtubule-binding domain hinders the myelinating capacity of an oligodendrocyte cell line. J Neurochem 107, 351-360.

[115] Clavaguera F, Bolmont T, Crowther RA, Abramowski D, Frank S, Probst A, Fraser G, Stalder AK, Beibel M, Staufenbiel M, Jucker M, Goedert M, Tolnay M (2009) Transmission and spreading of tauopathy in transgenic mouse brain. Nat Cell Biol 11, 909-913.

[116] Karch CM, Jeng AT, Goate AM (2012) Extracellular Tau levels are influenced by variability in Tau that is associated with tauopathies. J Biol Chem 287, 42751-42762.

[117] Ittner LM, Götz J (2011) Amyloid-beta and tau - a toxic pas de deux in Alzheimer's disease. Nat Rev Neurosci 12, 65-72.

[118] Ballard C, Gauthier S, Corbett A, Brayne C, Aarsland D, Jones E (2011) Alzheimer's disease. Lancet 377, 1019-1031.

[119] Götz J, Ittner A, Ittner LM (2012) Tau-targeted treatment strategies in Alzheimer's disease. Br J Pharmacol 165, 1246-1259. 